\title{
Urine-derived stem cells for potential use in bladder repair
}

\author{
Danian Qin ${ }^{1}$, Ting Long ${ }^{1}$, Junhong Deng ${ }^{2,3}$ and Yuanyuan Zhang ${ }^{3 *}$
}

\begin{abstract}
Engineered bladder tissues, created with autologous bladder cells seeded on biodegradable scaffolds, are being developed for use in patients who need cystoplasty. However, in individuals with organ damage from congenital disorders, infection, irradiation, or cancer, abnormal cells obtained by biopsy from the compromised tissue could potentially contaminate the engineered tissue. Thus, an alternative cell source for construction of the neo-organ would be useful. Although other types of stem cells have been investigated, autologous mesenchymal stem cells (MSCs) are most suitable to use in bladder regeneration. These cells are often used as a cell source for bladder repair in three ways - secreting paracrine factors, recruiting resident cells, and trans-differentiation, inducing MSCs to differentiate into bladder smooth muscle cells and urothelial cells. Adult stem cell populations have been demonstrated in bone marrow, fat, muscle, hair follicles, and amniotic fluid. These cells remain an area of intense study, as their potential for therapy may be applicable to bladder disorders.

Recently, we have found stem cells in the urine and the cells are highly expandable, and have self-renewal capacity and paracrine properties. As a novel cell source, urine-derived stem cells (USCs) provide advantages for cell therapy and tissue engineering applications in bladder tissue repair because they originate from the urinary tract system. Importantly, USCs can be obtained via a noninvasive, simple, and low-cost approach and induced with high efficiency to differentiate into bladder cells.
\end{abstract}

\footnotetext{
* Correspondence: Yzhang@wakehealth.edu

${ }^{3}$ Wake Forest University institute for Regenerative Medicine, Winston-Salem, NC 27106, USA

Full list of author information is available at the end of the article
}

\section{Introduction}

Stem cell-based therapy for bladder repair is most relevant to congenital bladder conditions (for example, bladder exstrophy) or conditions such as radiation damage, infection, interstitial cystitis, neuropathic small bladder disease, and bladder cancer. Chronic bladder diseases cause reduced contractility and compliance, form heavy scar tissue, and significantly reduce bladder volume (end-stage bladder disease). To treat invasive malignancies or endstage bladder diseases, a partial or total cystectomy is often used, followed by the creation of a neo-bladder or a continent urinary reservoir with an intestinal segment or gastric flap [1] to restore bladder function and increase its volume. However, using bowel tissue for this purpose commonly causes complications, such as excess mucus secretion, urinary tract infection, stone formation, and, most importantly, increased risk for malignancy, particularly adenocarcinoma, because of histological changes in the intestinal mucosa after long-term exposure to urine. Recent studies showed that all children with neurogenic bladder disease are at increased risk of bladder cancer regardless of exposure to intestine [2]. Therefore, new clinical and surgical techniques are needed to allow these patients to live healthier and more normal lives.

Bladder reconstruction with tissue engineering technology is possible through the use of normal autologous bladder cells seeded on biodegradable scaffolds [3]. However, in patients with end-stage bladder diseases or muscle-invasive bladder cancer, healthy autologous bladder cells might not be available. Concomitant development of a healthy, cancer-free stem cell source and an optimal three-dimensional nano-fibrous polymer scaffold are promising developments for use in patients who require cystoplasty.

Stem cells have shown potential as a therapeutic strategy for various tissue repairs, including of urinary bladder. Multiple types of cells have been used in preclinical animal models to repair or regenerate bladder tissue, employing either trans-differentiation or paracrine effects to stimulate endogenous cells participating in tissue
C Biomed Central 
regeneration. These stem cells include pluripotent stem cells such as embryonic stem cells (ESCs), induced pluripotent stem cells (iPSCs) [4], multi-potent mesenchymal stem cells (MSCs), bone marrow-derived mesenchymal stromal cells (BMSC) [5-9], adipose-derived stem cells [10], hair follicle stem cells [11,12], umbilical MSCs [13], urothelial stem cells [14] and, most recently, urinederived stem cells (USCs) $[15,16]$.

ESCs or iPSCs are naturally programmed to divide continuously and remain undifferentiated. Although these cells can give rise to ectodermal, mesodermal, or endodermal cell lineages, a significant risk of teratoma exists. Any undifferentiated ESCs or iPSCs placed in the body might continue to divide in an uncontrolled manner, forming tumors. In addition, it is time consuming ( 4 months) to derive and characterize iPSCs from an individual. Furthermore, low efficiency of cell differentiation, genetic abnormalities, and high cost prohibit clinical applicability. Even so, a few studies with ESCs or iPSCs for bladder tissue engineering have been reported. Frimberger and colleagues [17] reported that human embryoid body-derived stem cells showed improved migration in the presence of mature human bladder smooth muscle cells (SMCs) and urothelial cells (UCs). In addition, Moad and colleagues [4] reported the generation of human iPSCs derived from normal, ageing, human urinary tract tissue. These iPSCs were more efficient than skin-derived iPSCs in undergoing bladder differentiation as shown by expression of urothelialspecific markers (uroplakins, claudins, and cytokeratin) and stromal smooth muscle markers (alpha-smoothmuscle actin, calponin, and desmin), indicating the importance of organ-specific iPSCs for tissue-specific studies. Immobilized cell lines are not suitable for bladder regeneration due to safety concerns. Therefore, multi-potent adult stem cells are currently used in bladder repair and reconstruction.

\section{Mesenchymal stem cells for bladder repair}

To be used successfully in therapies, MSCs must be directed to differentiate into the desired type of tissue. Three types of bladder cells, SMCs, UCs, and endothelial cells, are required for bladder regeneration [5-7,18-24]. Via trans-differentiation, MSCs can give rise to all three types in the bladder. In addition, MSCs possess paracrine effects, with anigogenic, anti-apoptosis, anti-fibrosis, antiinflammatory properties [5-7]. BMSCs promote angiogenesis and increase cell viability of implanted UCs when both BMSCs and UCs seeded on biomaterial were transplanted in vivo [25]. Hypoxic stress increases generation of several of these cytokines and growth factors [26,27]. Thus, MSCs can recruit resident stem cells participating in tissue repair. Furthermore, MSCs purportedly exhibit low immunogenicity, allowing allogeneic applications [28-30].
MSCs have several advantages for tissue repair [18-24]: (i) they do not induce teratoma or malignant tumors; (ii) they can generate a large amount of cells within 4 weeks; (iii) they are highly efficient in giving rise to functional bladder cells, such as SMCs; (iv) they secrete paracrine factors that allow stem cells to be tolerated by the host's immune system; and (v) their use avoids general ethical concerns that accompany use of other types of stem cells.

Although BMSCs or adipose-derived stem cells are the most commonly used MSCs, they have some limitations, such as low differentiation capacity $(<5 \%)$ of UCs (endodermal lineage), short lifespan in vitro $(<10$ passages in BMSCs), and they require invasive collection procedures [31-34]. Thus, the ideal stem cell sources for bladder repair would: (i) be able to differentiate into functional UCs, endothelial cells, and peripheral neurocytes with high efficiency (these promote bladder contractility and compliance ability, and restore histological structures with innate vasculature and innervation); (ii) allow collection via a non-invasive, simple, safe, and low-cost method; (iii) have universal or 'off the shelf' availability; and (iv) generate tissue-specific or organ-specific stem cells from the urinary tract system. Currently, it is unknown whether such a 'perfect' stem cell exists. We do know, however, that certain cell types are more favorable than others.

\section{Urine-derived stem cells as a novel cell source}

Although stem cells are a very small cell population, they play an important role in replacing aged, injured, and diseased cells and promoting tissue regeneration from organs where they originate. We recently found that a subpopulation of cells isolated from urine possess biological characteristics similar to MSCs; that is, clonogenicity, cell growth patterns, expansion capacity [15,35], cell surface marker expression profiles [15], multipotent differentiation capacity [16,36-40], pro-angiogenic paracrine effects [41,42], immunomodulatory properties [43] and easily induced iPSCs [44]. Thus, we have termed these cells 'urinederived stem cells' or USCs (Figure 1). USCs consistently expressed MSC/pericyte markers and some key cell surface markers, but not hematopoietic stem cell markers (except for MHC-1), endothelial cell markers (CD31), or human leukocyte antigen (locus) DR (HLA-DR). Compared to other MSCs, USCs have several advantages: (i) they can be collected using a simple, safe, low-cost and non-invasive procedure; (ii) they display telomerase activity so that they are able to generate more cells; and (iii) they differentiate into SMCs, UCs and endothelial cells with high efficiency (Table 1).

\section{Proliferation capacity of urine-derived stem cells}

USCs can be obtained from voided urine and can generate a large number of cells from a single clone [37,38]. These cells possess highly proliferative capacity because 


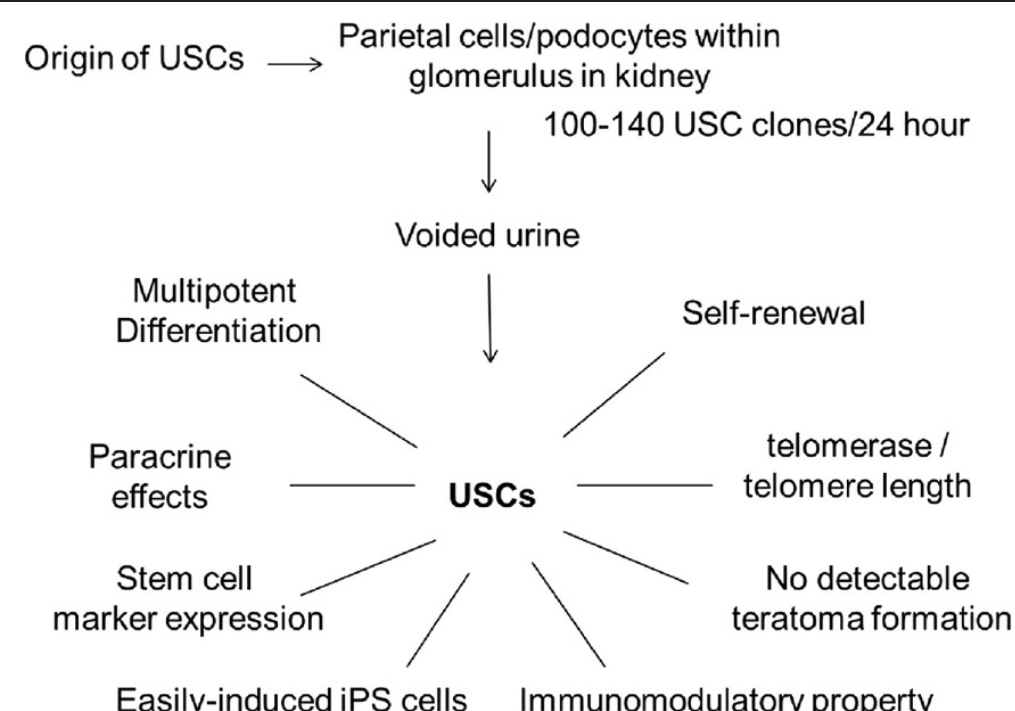

Figure 1 Schematic illustration of the origin and biological characteristics of urine-derived stem cells (USCs). USCs, a subpopulation of cells isolated from urine, possess biological characteristics similar to mesenchymal stem cells.

Table 1 Comparison of various stem cell types used for bladder repair

\begin{tabular}{|c|c|c|c|c|c|}
\hline Cell type/parameters & BMSCs $[5-9,19,45-50]$ & $\begin{array}{l}\text { ASCs } \\
{[51,52]}\end{array}$ & $\begin{array}{l}\text { USCs } \\
{[15,16,35,36,38-40,53-55]}\end{array}$ & ESC/iPSCs [56] & $\begin{array}{l}\text { Bladder SMCs } \\
\text { and UCs }\end{array}$ \\
\hline $\begin{array}{l}\text { Self-renewal and } \\
\text { expansion capability }\end{array}$ & Limited, PD 30 & & High, PD 60-70 & Very high, PD >200 & $\begin{array}{l}\text { Limited, PD } \\
<30\end{array}$ \\
\hline $\begin{array}{l}\text { Multi-lineage } \\
\text { differentiation capability }\end{array}$ & $\begin{array}{l}\text { Multipotent, but mainly limited } \\
\text { within mesodermal cell lineages } \\
{[5-9]}\end{array}$ & $\begin{array}{l}\text { Similar to } \\
\text { BMSCs } \\
{[52,54]}\end{array}$ & $\begin{array}{l}\text { Multipotent differentiation } \\
\text { potential }[15,16,35,36]\end{array}$ & $\begin{array}{l}\text { Pluri-potent (can form } \\
\text { all lineages of the body) } \\
{[56]}\end{array}$ & None \\
\hline $\begin{array}{l}\text { Urothelial and } \\
\text { endothelial } \\
\text { differentiation capability }\end{array}$ & Low $(<10 \%)$ & Low (10\%) & High (60-85\%) [39-41] & Low & \\
\hline $\begin{array}{l}\text { Telomerase activity } \\
\text { (TA)/telomere length }\end{array}$ & Cannot be detected & $\begin{array}{l}\text { Cannot be } \\
\text { detected }\end{array}$ & $\begin{array}{l}\text { Up to } 75 \% \text { USC clones possess } \\
\text { TA and relatively long } \\
\text { telomeres }\end{array}$ & $\begin{array}{l}\text { Possess TA and long } \\
\text { telomeres }\end{array}$ & None \\
\hline Harvesting approach & Invasive & Invasive & $\begin{array}{l}\text { Non-invasive, simple, cost-low, } \\
\text { safe [56] }\end{array}$ & $\begin{array}{l}\text { Invasive to harvest } \\
\text { somatic cells for iPSCs }\end{array}$ & Invasive \\
\hline Pure stem cell isolation & Difficult & Difficult & Very easy & Easy & None \\
\hline $\begin{array}{l}\text { Number of stem cells } \\
\text { harvested }\end{array}$ & $\begin{array}{l}1 \mathrm{MSC} / 10^{4} \text { bone marrow stromal } \\
\text { cells in new borns, } 1 \mathrm{MSC} / 10^{6} \\
{[19]}\end{array}$ & & $\begin{array}{l}100-140 \text { USC clones/24 hour } \\
\text { urine in adult }[55,57]\end{array}$ & & Unknown \\
\hline $\begin{array}{l}\text { Angiogenic trophic } \\
\text { factors }\end{array}$ & Yes & Yes & Yes & Unknown & Moderate \\
\hline $\begin{array}{l}\text { Immuno-modulatory } \\
\text { properties }\end{array}$ & Yes & Yes & Yes & Unknown & Unknown \\
\hline $\begin{array}{l}\text { Rejection after } \\
\text { implanted in vivo }\end{array}$ & \multicolumn{3}{|c|}{$\begin{array}{l}\text { No rejection reaction as allogenous or even xenogenous cells (for example, } \\
\text { human BMSCS, USCs) implanted in rodent, rabbit, or canine models }\end{array}$} & Likely to be rejected & $\begin{array}{l}\text { No rejection as } \\
\text { autogenous } \\
\text { cells }\end{array}$ \\
\hline Oncogenic potential & No & No & No & Yes & None \\
\hline Clinic trial utility & Potential & Potential & Potential & Safety concern & Yes \\
\hline
\end{tabular}

ASC, adipose-derived stem cell; BMSC, bone marrow-derived mesenchymal stromal cell; ESC, embryonic stem cell; iPSC, induced pluripotent stem cell; MSC, mesenchymal stem cell; PD, population doubling; SMC, smooth muscle cell; UC, urothelial cell; USC, urine-derived stem cell. 
they maintain higher telomerase activity and longer telomere length compared to BMSCs. Up to $75 \%$ of USCs collected from middle-aged individuals expressed telomerase activity (USCs- $\mathrm{TA}^{+}$) and retained long telomere length [58], but USCs-TA ${ }^{+}$decline to 50 to $60 \%$ of the USCs in people aged 50 years old or older. USCs-TA ${ }^{+}$ can be maintained for up to 20 passages with 67 population doublings, indicating that a single USC can generate up to $2^{67}$ cells within 14 weeks. In contrast, USCs-TA ${ }^{-}$ grow for only 8 to 10 passages with 34 population doublings. Importantly, either USCs-TA ${ }^{+}$or USCs-TA ${ }^{-}$display normal karyotypes in culture medium even after several passages. They did not form teratomas 3 months after renal subcapsular cell implantation [58]. We can now obtain 100 to 140 USC clones/24 h urine from each individual [35]. About $1.4 \times 10^{9}$ cells are needed for potential use in bladder reconstruction with cell-seeded technology [3]. Thus, two urine samples containing 20 to 30 USC clones in $400 \mathrm{ml}$ can provide ample cells $\left(1.5 \times 10^{9}\right.$ USCs at passage 4$)$ within 4 to 5 weeks to be used in cell-based therapy for bladder repair.

\section{Multipotent differentiation potential of urine-derived stem cells}

Our data demonstrated that USCs are capable of osteogenic, chondrogenic and adipogenic myogenic, neurogenic and endothelial differentiation [15]. After being induced in the appropriate condition in vitro, each type of differentiated USC expressed specific markers at the gene, protein, and cellular levels. Following implantation in vivo, induced USCs can form functional bone, cartilage, fat, muscle, endothelium, and urothelium tissue [15]. However, signaling pathways involved in USCs differentiation and proliferation need further investigation.

\section{Urine-derived stem cell differentiation into bladder cells}

For bladder tissue engineering, urothelial cells are needed for creating bladder mucosa, smooth muscle cells for building up bladder wall, and endothelial cells for forming blood vessels. However, a challenge in urological tissue regeneration is generating urothelial cells from MSCderived cells. Although BMSCs, the most commonly used MSC source, can efficiently differentiate into SMCs, only $5 \%$ of BMSCs can give rise to the cells expressing urothelial markers in vitro [40]. One of the most likely reasons for this is that true stem cells in bone marrow stromal cells are very rare, depending on donor age $\left(1 / 10^{4}\right.$ cells in newborns, but $1 / 10^{6}$ in older individuals). Furthermore, it is very difficult to isolate stem cells from the large amount of somatic cells. Anumanthan and colleagues [45] reported that use of embryonic rat bladder mesenchymal cells co-implanted with allogeneic rat BMSCs induced bladder tissue structure with cells expressing urothelial and muscle markers. As well as urothelial differentiation of MSCs, Nagele and colleagues [59] reported that human urothelial cells can be harvested from bladder washings and primary cultures of these were successfully established from half the bladder wash samples. The cultured cells formed multilayered urothelial sheets for potential use in urinary tract tissue reconstruction. Recently, Drewa and colleagues [12] found that hair follicle stem cells from rat whisker hair follicles differentiated into cells expressing epithelial cell markers (cytokeratin 7, cytokeratin 8, cytokeratin 18) during culture in UC-conditioned medium for 2 weeks in vitro.

Using the same inductive medium as in the BMSC study [6], we found that 60 to $70 \%$ of USCs differentiated into cells expressing UC-specific genes (uroplakinIa/III) and protein markers, and had urothelial barrier function and tight junction ultrastructures. Urothelial differentiated USCs also expressed the genes encoding ZO-1, E-cadherin, and cingulin as well as the protein products (associated with tight junctions) in a dose- and time-dependent manner. The barrier function of induced USCs reached the mature function of UCs isolated from bladder tissue 14 days after induction, significantly higher than for non-induced USCs, indicating that the USCs possessed stem cell plasticity.

USCs can efficiently give rise to functional cells of the SMC lineage. Smooth muscle differentiated USCs expressed a-SM actin and calponin, desmin and myosin, and smoothelin at both the gene and protein levels $[15,16]$. The mRNA and protein levels of these markers increased significantly with time in differentiation media. Functional studies demonstrated that these SMCs have contractile properties in vitro. Myogenic differentiated USCs formed multiple layers of SMCs beneath UC layers when subcutaneously implanted in a nude mouse model $[15,38]$. The SMCs stained positively for a-SM actin, desmin, and myosin. Scaffolds containing urothelial differentiated USCs generated stratified layers in vivo and stained positive for uroplakin-Ia and uroplakin-III (urothelial markers) [14,38].

We found that USCs differentiate into cells of the endothelial lineage when grown in endothelial differentiation medium containing $2 \mathrm{ng} / \mathrm{ml}$ vascular endothelial growth factor (VEGF) for 12 days [15]. In vitro 'vessel forming' was displayed 18 hours after differentiated USCs $\left(5 \times 10^{3}\right.$ cells) were seeded onto Matrigel. The differentiated cells began to express the specific gene and protein markers of endothelial cells (CD31, vWF, KDR, FLT-1, FLT-1, eNOS and VE-cadherin). Induced USCs demonstrated intense immunofluorescent staining for these markers compared to non-differentiated USCs. Importantly, USCs can be efficiently differentiated into endothelial cells with barrier function. Neovessel formation occurred after induced USCs were subcutaneously implanted in an athymic mouse model $[40,41]$. 
Immunoregulatory properties of urine-derived stem cells Regulatory $\mathrm{T}$ cells play an important role in induction of peripheral tolerance, inhibition of pro-inflammatory immune responses, and decreased immune reactions. We recently demonstrated that USCs can impart profound immunomodulatory effects, inhibit proliferation of peripheral blood mononuclear cells (PBMNCs; T and B cells), and secrete IL-6 and IL-8 [43]. PBMNCs proliferated when mixed with other cells due to immune stimulation. The PBMNC concentration in USC wells was much less than that in BMSC culture wells. Bromodeoxyuridine colorimetric enzyme-linked immunosorbent assays showed there was less bromodeoxyuridine label in the mixed USC and PBMNC culture wells compared to the BMSC culture wells. CD80 and CD86 expressed on the surface of antigen-presenting cells interact with cytotoxic $\mathrm{T}$ lymphocyte antigen -4 expressed on activated $\mathrm{T}$ cells and mediate critical T-cell inhibitory signals. Flow cytometry showed that $3.35 \%$ of the BMSCs were positive for CD80 (versus $1.05 \%$ of USCs), and $1.3 \%$ of the BMSCs were positive for CD86 (versus $0.55 \%$ of USCs). Human cytokine release arrays showed that IL-6 and IL8 concentrations were elevated after stimulation by PBMNCs in USC supernatant to a greater degree than in BMSC supernatant. IL- 6 and IL- 8 might be the main immunomodulatory cytokines to target in future studies aimed at preventing and treating diabetic bladder tissue lesions, other immune system disorders, or rejection of transplanted organs.

\section{Origin of urine-derived stem cells}

USCs isolated from urine obtained from the upper urinary tract are similar to voided USCs in morphology, cell phenotype, growth pattern, and differentiation capacity [36]. We found strong evidence that the voided USCs originate from the kidney, because cells obtained from women who had received transplanted kidneys from male donors contained the Y chromosome and expressed normal renal cell markers (PAX2 and PAX8), podocytes and parietal cells (which populate the glomerulus in kidney [60-68]), and specific gene and protein markers (synaptopodin and podocin). USCs also expressed CD146 at a rate similar to that expressed in parietal cells and podocytes in glomerulus, while bladder and ureter UCs and SMCs did not, indicating that USCs are likely transitional cells at the parietal cell/podocyte interface originating from renal tissue. Recently, parietal cells have been considered as stem cells in the glomeruli, displaying self-renewal properties and the potential to give rise to podocytes and proximal tubular cells [60-68]. Parietal cells are commonly obtained from kidney tissue biopsies, but the isolation of pure parietal cells is difficult [63-68].

In chronic bladder diseases, USCs might be a good cell source for bladder tissue regeneration because the cells from the upper urinary tract are normal. For treatment of end-stage bladder diseases or muscle-invasive bladder cancer, using bladder tissue created with USCs would be superior to bladder reconstruction using intestinal segments.

\section{Impact of angiogenic growth factors on urine-derived stem cell ingrowth and differentiation in vivo}

USCs can secrete angiogenic growth factors and cytokines, but require a favorable microenvironment to do so. We demonstrated that use of genetically modified stem cells via transfection of the VEGF gene significantly promoted myogenic differentiation of USCs and induced angiogenesis and innervation [69]. However, virally delivered VEGF caused several side effects in our animal model, including hyperemia, hemorrhage, and even death [53]. Thus, a safer approach is needed for stem cell therapy to increase angiogenesis and promote muscle regeneration. Adding exogenous angiogenic factors into biodegradable polymers as delivery vehicles can be beneficial to promote regeneration and tissue healing [57]. Alginate is one of the most commonly used natural hydrogels as an aqueous drug carrier for encapsulation because of its mild gelling conditions and tunable microsphere characteristics. Alginate microbeads also resist protein adsorption, making them attractive for in vivo studies [70]. Alginate microbeads deliver molecules in a controlled fashion, which can stably release active fibroblast growth factor (FGF)-1 for at least 3 weeks in vitro. This sustained release of FGF-1 promoted neovascularization in vivo without any side effects [71-73]. More recently, we found that a combination of growth factors (VEGF, insulin-like growth factor-1, FGF-1, plateletderived growth factor, hepatocyte growth factor and nerve growth factor) released locally from alginate microbeads induced USCs to differentiate into a myogenic lineage, enhanced revascularization and innervation, and stimulated resident cell growth in vivo [53]. In addition, when cultured on three-dimensional biomaterial, stem cells had significantly enhanced cell viability, proliferation, and differentiation in vitro, and promoted tissue formation in vivo, compared to cells cultured on two-dimensional plates [74].

\section{Biomaterials for bladder tissue regeneration}

Two types of biodegradable scaffolds are commonly used in cell-seeded tissue engineering for bladder reconstruction: natural collagen materials (that is, bladder submucosa [75] or small intestine submucosa $[39,76]$ and collagen type I matrix [77]); and synthetic polymers such as polyglycolic acid and poly(lactic-co-glycolic acid) [3,78], biocarbon [79], poly-L-lactic acid (PLLA) [8,9] and bacterial cellulose polymer [38]. Most degradable biomaterials promote cellular interaction and tissue 
development, and possess adequate mechanical and physical properties. However, natural collagen scaffolds cannot maintain a robust physical structure in an in vivo environment when used in total or subtotal bladder replacement, resulting in graft collapse, contraction, formation of fibrosis, and shrinkage of the new bladder, with resultant decreased bladder capacity [22]. A biomaterial that retains a hollow structure, and has antifibrosis properties and a three-dimensional porous microstructure for graft cell seeding would be highly desirable for creating a viable tissue-engineered bladder.

An ideal biological material for urethral tissue engineering would have high porosity and appropriate pore sizes to allow cell attachment, migration and penetration into the matrix after seeding, and it should be able to induce angiogenesis, be biodegradable, histocompatible, and have the least xenogenous antigens retained within the matrix for minimum inflammatory potential. The synthetic material nanofibrous PLLA appears to meet these criteria, as it possesses a three-dimensional, highly porous structure (50 to $200 \mu \mathrm{M}$ ), but has adequate tensile strength to maintain the shape of an engineered organ in vivo. The highly interconnected pore structure of the nanofibrous PLLA scaffolds is an excellent environment for cell growth and angiogenesis [80,81]. This allows abundant cell loading onto the scaffold, and induces microvessel network formation, thereby promoting in vivo tissue regeneration and wound healing [82-85]. It also allows the host's cells to participate in tissue remodeling processes by encouraging infiltration or migration into the matrix from the wound edges. Because of these properties, PLLA has been used in a number of tissue engineering studies [9,81,83,84,86-119], including on blood vessels $[86,88]$. Importantly, the nanofibrous PLLA scaffolds degrade significantly faster than control PLLA scaffolds because of their drastically higher surface area and fiber size [106], making them suitable for bladder tissue regeneration.

\section{Debated hypotheses}

Several assumptions are still controversial in bladder tissue regeneration research. First, trans-differentiation and paracrine effects are both critical in regeneration of various tissues. Although most studies have monitored the survival rate of implanted cells, cytokines and growth factors secreted from stem cells might play an important role in bladder repair [120].

Second, the need for addition of growth factors to induce angiogenesis is still debated. However, accumulating evidence shows that extrogenous growth factors improve blood support and tissue repair [121,122], especially in local tissues with poor blood supply or when large amounts of bladder tissue are being replaced. Growth factors may not be required where the local tissue possesses a rich blood supply or when only a small amount of bladder tissue needs replacement [22].

Third, should undifferentiated or differentiated MSCs be used in bladder repair [19]? Undifferentiated stem cells can secrete more paracrine factors than differentiated stem cells, but differentiated cells might possess more potential to replace dysfunctional somatic cells. Therefore, a 1:1 ratio of undifferentiated and differentiated cells might be optimal for bladder regeneration.

Fourth, both layered co-culture and sandwich coculture seeding techniques are used [20]. The former allows the interaction of epithelial-stromal cells, whereas the latter provides a histologic structure more similar to the normal structure, thereby preventing SMC loss during surgical procedures. In addition, expression of the protein signal sonic hedgehog in urothelial basal cells boosts and provokes increased stromal expression of Wnt protein signals, which in turn stimulate the proliferation of both urothelial and stromal cells.

\section{Future directions}

Using stem cells more efficiently for bladder regeneration requires improving angiogenesis, inducing innervation, and developing more suitable biomaterials in the next few years. High short-term cell retention and long-term engraftment after cell delivery allow more successful bladder tissue repair during regeneration. Cell retention within 24 hours of delivery in the bladder is relatively high (regardless of the cell type or scaffolds) when SMCs are seeded on the serosal side. However, UCs seeded on the luminal side of the scaffold are often lost during surgery procedures, washed out via the urine, or mechanically ejected via the urethral catheter. In addition, successfully retained cells start to die within the first week, most probably due to ischemia, inflammation, or apoptosis due to detachment from the extracellular matrix. Therefore, it is extremely important to increase viability of implanted stem cells early after cell transplantation. Several methods might help reach this goal: (i) using biomaterials with a porous micro-structure that might protect cell retention within the scaffold; (ii) keeping the cell-seeding scaffold construct wet in the culture media, and avoid drying it out during surgery; (iii) inducing angiogenesis or capillary network formation early in implantation with angiogenic growth factors released from microbeads or binding scaffolds in the site or using hypoxia as a pretreatment for implanted cells; and (iv) promoting revascularization (artery-capillary-venous system) at the mid or late stage after the implantation with biologically safe physical stimulation, including lower-frequency electrical stimulation or low-intensity ultrasound. These methods could extend the lifespan of implanted cells in vivo to provide better tissue repair with long-term release of paracrine factors and trans-differentiation, anti-fibroblast formation, and antiinflammatory and anti-apoptotic effects of MSCs. In 
addition, innervation is critical to create a functional bladder. Stimulating peripheral nerve growth into neo bladder tissue might be more efficacious than attempting to create neurogenic differentiation of MSCs.

\section{Conclusion}

Use of MSCs, which possess an excellent safety profile, for bladder tissue regeneration is highly feasible. Pre-clinical outcomes have been generally positive in restoring bladder contractility and volume in the partial (40\%) cystoplasty model. Autologous MSCs derived from patients would be a potential cell source for bladder repair. MSCs appear safe to use for urological tissue repair with no evidence of increased tumorigenesis after implantation. USCs possess MSC features, including self-renewal, multi-differentiation potential, and paracrine effects. As a novel cell source, USCs can be obtained via a non-invasive, simple, safe and low-cost approach, are highly expandable, give rise to bladder cells efficiently, and express telomerase activity but do not induce teratomas. Studies of implanted USCs in vivo will help to determine their impact on bladder tissue regeneration and monitor cell retention and engraftment over the longer term (beyond 3 months). Besides bladder tissue repair, USCs might also be a viable cell source for uretera or urethral tissue engineering and reconstruction, and for cell therapy in treatment of diabetic erectile dysfunction, vesicoureteral or anal reflux and other diseases.

Note: This article is part of a thematic series on Stem cells in genitourinary regeneration edited by John Jackson. Other articles in the series can be found online at http:// stemcellres.com/series/genitourinary

\section{Abbreviations}

BMSC: Bone marrow-derived mesenchymal stromal cell; ESC: Embryonic stem cell; FGF: Fibroblast growth factor; IL: Interleukin; iPSC: Induced pluripotent stem cell; MSC: Mesenchymal stem cell; PBMNC: Peripheral blood mononuclear cell; PLLA: Poly-L-lactic acid; SMC: Smooth muscle cell; UC: Urothelial cell; USC: Urine-derived stem cell; VEGF: Vascular endothelial growth factor.

\section{Competing interests}

The authors declare that they have no competing interests.

\section{Authors' information}

Danian Qin and Ting Long are first co-authors.

\section{Author details}

'Department of Physiology, Shantou University, Shantou, Guangdong 515041, China. 'Department of Urology, Guangzhou First people's Hospital, Guangzhou, Guangdong 510180, China. ${ }^{3}$ Wake Forest University institute for Regenerative Medicine, Winston-Salem, NC 27106, USA.

\section{References}

1. Mitchell ME: Bladder augmentation in children: where have we been and where are we going? BJU Int 2003, 92:29-34.

2. Higuchi TT, Granberg CF, Fox JA, Husmann DA: Augmentation cystoplasty and risk of neoplasia: fact, fiction and controversy. J Urol 2010, 184:2492-2496.

3. Atala A, Bauer SB, Soker S, Yoo JJ, Retik AB: Tissue-engineered autologous bladders for patients needing cystoplasty. Lancet 2006, 367:1241-1246.

4. Moad M, Pal D, Hepburn AC, Williamson SC, Wilson L, Lako M, Armstrong L, Hayward SW, Franco OE, Cates JM, Fordham SE, Przyborski S, Carr-Wilkinson J, Robson CN, Heer R: A novel model of urinary tract differentiation, tissue regeneration, and disease: reprogramming human prostate and bladder cells into induced pluripotent stem cells. Eur Urol 2013, 64:753-761.

5. Sharma AK, Bury MI, Fuller NJ, Marks AJ, Kollhoff DM, Rao MV, Hota PV, Matoka DJ, Edassery SL, Thaker H, Sarwark JF, Janicki JA, Ameer GA, Cheng EY: Cotransplantation with specific populations of spina bifida bone marrow stem/progenitor cells enhances urinary bladder regeneration. Proc Natl Acad Sci U S A 2013, 110:4003-4008.

6. Sharma AK, Bury MI, Marks AJ, Fuller NJ, Meisner JW, Tapaskar N, Halliday LC, Matoka DJ, Cheng EY: A nonhuman primate model for urinary bladder regeneration using autologous sources of bone marrow-derived mesenchymal stem cells. Stem Cells 2011, 29:241-250.

7. Sharma AK, Fuller NJ, Sullivan RR, Fulton N, Hota PV, Harrington DA, Villano J, Hagerty JA, Cheng EY: Defined populations of bone marrow derived mesenchymal stem and endothelial progenitor cells for bladder regeneration. J Urol 2009, 182:1898-1905.

8. Tian H, Bharadwaj S, Liu Y, Ma PX, Atala A, Zhang Y: Differentiation of human bone marrow mesenchymal stem cells into bladder cells: potential for urological tissue engineering. Tissue Eng Part A 2010, 16:1769-1779.

9. Tian H, Bharadwaj S, Liu Y, Ma H, Ma PX, Atala A, Zhang Y: Myogenic differentiation of human bone marrow mesenchymal stem cells on a 3D nano fibrous scaffold for bladder tissue engineering. Biomaterials 2010, 31:870-877.

10. Salem SA, Hwie AN, Saim A, Chee Kong CH, Sagap I, Singh R, Yusof MR, Md Zainuddin Z, Hj Idrus R: Human adipose tissue derived stem cells as a source of smooth muscle cells in the regeneration of muscular layer of urinary bladder wall. Malays J Med Sci 2013, 20:80-87.

11. Drewa T, Joachimiak R, Kaznica A, Sarafian V, Pokrywczynska M: Hair stem cells for bladder regeneration in rats: preliminary results. Transplant Proc 2009, 41:4345-4351.

12. Drewa T, Joachimiak R, Bajek A, Gagat M, Grzanka A, Bodnar M, Marszalek A, Debski R, Chlosta P: Hair follicle stem cells can be driven into a urotheliallike phenotype: an experimental study. Int J Urol 2013, 20:537-542.

13. Yuan H, Zhuang Y, Xiong J, Zhi W, Liu L, Wei Q, Han P: Human umbilical mesenchymal stem cells-seeded bladder acellular matrix grafts for reconstruction of bladder defects in a canine model. PLoS One 2013, 8:e80959.

14. Kurzrock EA, Lieu DK, Degraffenried LA, Chan CW, Isseroff RR: Labelretaining cells of the bladder: candidate urothelial stem cells. Am J Physiol Renal Physiol 2008, 294:F1415-F1421.

15. Bharadwaj S, Liu G, Shi Y, Wu R, Yang B, He T, Fan Y, Lu X, Zhou X, Liu H, Atala A, Rohozinski J, Zhang $Y$ : Multi-potential differentiation of human urine-derived stem cells: potential for therapeutic applications in urology. Stem Cells 2013, 31:1840-1856.

16. Zhang $Y$, McNeill E, Tian H, Soker S, Andersson KE, Yoo JJ, Atala A: Urine derived cells are a potential source for urological tissue reconstruction. J Urol 2008, 180:2226-2233.

17. Frimberger D, Morales N, Gearhart JD, Gearhart JP, Lakshmanan Y: Human embryoid body-derived stem cells in tissue engineering-enhanced migration in co-culture with bladder smooth muscle and urothelium. Urology 2006, 67:1298-1303.

18. Zhang Y, Liu G, Kropp BP: Re-epithelialization of demucosalized stomach patch with tissue-engineered urothelial mucosa combined with Botox $A$ in bladder augmentation. BJU Int 2012, 110:E106-E112.

19. Zhang Y, Lin HK, Frimberger D, Epstein RB, Kropp BP: Growth of bone marrow stromal cells on small intestinal submucosa: an alternative cell source for tissue engineered bladder. BJU Int 2005, 96:1120-1125.

20. Zhang Y, Kropp BP, Moore P, Cowan R, Furness PD 3rd, Kolligian ME, Frey P, Cheng EY: Coculture of bladder urothelial and smooth muscle cells on small intestinal submucosa: potential applications for tissue engineering technology. J Urol 2000, 164:928-934. discussion 934-925.

21. Zhang $Y$, Kropp BP, Lin HK, Cowan R, Cheng EY: Bladder regeneration with cell-seeded small intestinal submucosa. Tissue Eng 2004, 10:181-187. 
22. Zhang Y, Frimberger D, Cheng EY, Lin HK, Kropp BP: Challenges in a larger bladder replacement with cell-seeded and unseeded small intestinal submucosa grafts in a subtotal cystectomy model. BJU Int 2006, 98:1100-1105.

23. Zhang $Y$ : Bladder reconstruction by tissue engineering - with or without cells? J Urol 2008, 180:10-11.

24. Sharma AK, Hota PV, Matoka DJ, Fuller NJ, Jandali D, Thaker H, Ameer GA, Cheng EY: Urinary bladder smooth muscle regeneration utilizing bone marrow derived mesenchymal stem cell seeded elastomeric poly(1,8-octanediol-co-citrate) based thin films. Biomaterials 2010, 31:6207-6217.

25. Shen J, Fu X, Ou L, Zhang M, Guan Y, Wang K, Che Y, Kong D, Steinhof G, Li W, Yu Y, Ma N: Construction of ureteral grafts by seeding urothelial cells and bone marrow mesenchymal stem cells into polycaprolactonelecithin electrospun fibers. Int J Artif Organs 2010, 33:161-170.

26. Cicione C, Muinos-Lopez E, Hermida-Gomez T, Fuentes-Boquete I, Diaz-Prado S, Blanco FJ: Effects of severe hypoxia on bone marrow mesenchymal stem cells differentiation potential. Stem Cells Int 2013, 2013:232896.

27. Garg A, Newsome Philip N: Bone marrow mesenchymal stem cells and liver regeneration: believe the hypoxia! Stem Cell Res Ther 2013, 4:108.

28. Purandare B, Teklemariam $T$, Zhao L, Hantash BM: Temporal HLA profiling and immunomodulatory effects of human adult bone marrow- and adipose-derived mesenchymal stem cells. Regen Med 2014, 9:67-79.

29. Schafer S, Calas AG, Vergouts M, Hermans E: Immunomodulatory influence of bone marrow-derived mesenchymal stem cells on neuroinflammation in astrocyte cultures. J Neuroimmunol 2012, 249:40-48.

30. Lee JM, Jung J, Lee HJ, Jeong SJ, Cho KJ, Hwang SG, Kim GJ: Comparison of immunomodulatory effects of placenta mesenchymal stem cells with bone marrow and adipose mesenchymal stem cells. Int Immunopharmacol 2012, 13:219-224.

31. Murphy MB, Moncivais K, Caplan Al: Mesenchymal stem cells: environmentally responsive therapeutics for regenerative medicine. Exp Mol Med 2013, 45:e54.

32. Dimarino AM, Caplan Al, Bonfield TL: Mesenchymal stem cells in tissue repair. Front Immunol 2013, 4:201.

33. Singer NG, Caplan Al: Mesenchymal stem cells: mechanisms of inflammation. Annu Rev Pathol 2011, 6:457-478.

34. Meirelles Lda S, Fontes AM, Covas DT, Caplan Al: Mechanisms involved in the therapeutic properties of mesenchymal stem cells. Cytokine Growth Factor Rev 2009, 20:419-427.

35. Lang R, Liu G, Shi Y, Bharadwaj S, Leng X, Zhou X, Liu H, Atala A, Zhang Y. Self-renewal and differentiation capacity of urine-derived stem cells after urine preservation for 24 hours. PLoS One 2013, 8:e53980.

36. Bharadwaj S, Liu G, Shi Y, Markert C, Andersson KE, Atala A, Zhang Y: Characterization of urine-derived stem cells obtained from upper urinary tract for use in cell-based urological tissue engineering. Tissue Eng Part A 2011, 17:2123-2132.

37. Bharadwaj S, Wu S, Hodges S, Atala A, Zhang Y: Skeletal muscle differentiation of human urine-derived stem cells for injection therapy in the treatment of stress urinary incontinence. J Urology 2011, 184:E681.

38. Bodin A, Bharadwaj S, Wu S, Gatenholm P, Atala A, Zhang Y: Tissue-engineered conduit using urine-derived stem cells seeded bacterial cellulose polymer in urinary reconstruction and diversion. Biomaterials 2010, 31:8889-8901.

39. Wu S, Liu Y, Bharadwaj S, Atala A, Zhang Y: Human urine-derived stem cells seeded in a modified 3D porous small intestinal submucosa scaffold for urethral tissue engineering. Biomaterials 2011, 32:1317-1326.

40. Wu S, Wang Z, Bharadwaj S, Hodges SJ, Atala A, Zhang Y: Implantation of autologous urine derived stem cells expressing vascular endothelial growth factor for potential use in genitourinary reconstruction. J Urol 2011, 186:640-647

41. Liu G, Wu G, Bharadwaj S, Soker S, Atala A, Zhang Y: Implantation of autologous urine derived stem cells expressing vascular endothelial growth factor for potential use in the treatment of neurovascular erectile dysfunction. J Urol 2011, 185:e304-e305.

42. Liu G, Wu S, Bharadwaj S, Soker S, Atala A, Zhang Y: Promoting muscle and nerve regeneration after human urine-derived stem cells expression of vascular endothelial growth factor for potential use in treatment of stress urinary incontinency. J Urol 2011, 185:e462.

43. Wu RP, Soland M, Liu G, Shi YA, Bharadwaj S, Atala A, Almeida-Porada G, Zhang Y: Immunomodulatory properties of urine derived stem cells. In
The 3rd Annual Regenerative Medicine Foundation Conference 2012 Abstract Book; Charlotte, NC, USA; 2012. [https://imgsvr.eventrebels.com/ERImg/00/91/ 88/2337906/27482-2-10311.pdf]

44. Guan X, Shi Y, Markert CD, Mack DL, Jones TN, Moorefield EC, Zhang Y, Childers MK: Rapid generation of induced pluripotent stem cells (iPSCs) from the urine of a patient with Duchenne muscular dystrophy. Mol Ther 2012, 20:S111.

45. Anumanthan G, Makari JH, Honea L, Thomas JC, Wills ML, Bhowmick NA, Adams MC, Hayward SW, Matusik RJ, Brock JW 3rd, Pope JC: Directed differentiation of bone marrow derived mesenchymal stem cells into bladder urothelium. J Urol 2008, 180:1778-1783.

46. Chen S, Zhang HY, Zhang N, Li WH, Shan H, Liu K, Yang Y: Treatment for chronic ischaemia-induced bladder detrusor dysfunction using bone marrow mesenchymal stem cells: an experimental study. Int J Mol Med 2012, 29:416-422.

47. Ning J, Li C, Li H, Chang J: Bone marrow mesenchymal stem cells differentiate into urothelial cells and the implications for reconstructing urinary bladder mucosa. Cytotechnology 2011, 63:531-539.

48. Drzewiecki BA, Thomas JC, Tanaka ST: Bone marrow-derived mesenchymal stem cells: current and future applications in the urinary bladder. Stem Cells Int 2011, 2010:765167.

49. Zhang K, Shi B, Chen J, Zhang D, Zhu Y, Zhou C, Zhao H, Jiang X, Xu Z: Bone marrow mesenchymal stem cells induce angiogenesis and promote bladder cancer growth in a rabbit model. Urol Int 2010, 84:94-99.

50. Chung SY, Krivorov NP, Rausei V, Thomas L, Frantzen M, Landsittel D, Kang YM, Chon $\mathrm{CH}, \mathrm{Ng}$ CS, Fuchs GJ: Bladder reconstitution with bone marrow derived stem cells seeded on small intestinal submucosa improves morphological and molecular composition. J Urol 2005, 174:353-359.

51. Jack GS, Zhang R, Lee M, Xu Y, Wu BM, Rodriguez LV: Urinary bladder smooth muscle engineered from adipose stem cells and a three dimensional synthetic composite. Biomaterials 2009, 30:3259-3270.

52. Zhang H, Qiu X, Shindel AW, Ning H, Ferretti L, Jin X, Lin G, Lin CS, Lue TF: Adipose tissue-derived stem cells ameliorate diabetic bladder dysfunction in a type II diabetic rat model. Stem Cells Dev 2012, 21:1391-1400.

53. Liu G, Pareta RA, Wu R, Shi Y, Zhou X, Liu H, Deng C, Sun X, Atala A, Opara EC, Zhang Y: Skeletal myogenic differentiation of urine-derived stem cells and angiogenesis using microbeads loaded with growth factors. Biomaterials 2013, 34:1311-1326.

54. Liu G, Wang X, Sun X, Deng C, Atala A, Zhang Y: The effect of urine-derived stem cells expressing VEGF loaded in collagen hydrogels on myogenesis and innervation following after subcutaneous implantation in nude mice. Biomaterials 2013, 34:8617-8629.

55. Chun SY, Kim HT, Lee JS, Kim MJ, Kim BS, Kim BW, Kwon TG: Characterization of urine-derived cells from upper urinary tract in patients with bladder cancer. Urology 2012, 79:1186 e1181-1187.

56. Xue Y, Cai X, Wang L, Liao B, Zhang H, Shan Y, Chen Q, Zhou T, Li X, Hou J, Chen S, Luo R, Qin D, Pei D, Pan G: Generating a non-integrating human induced pluripotent stem cell bank from urine-derived cells. PLoS One 2013, 8:e70573.

57. Camarata PJ, Suryanarayanan R, Turner DA, Parker RG, Ebner TJ: Sustained release of nerve growth factor from biodegradable polymer microspheres. Neurosurgery 1992, 30:313-319.

58. Shi YA, Liu GH, Bharadwaj S, Atala A, Zhang Y: Urine derived stem cells with high telomerase activity for cell based therapy in urology. J Urol 2012, 187:e302.

59. Nagele U, Maurer S, Feil G, Bock C, Krug J, Sievert KD, Stenzl A: In vitro investigations of tissue-engineered multilayered urothelium established from bladder washings. Eur Urol 2008, 54:1414-1422.

60. Lasagni L, Ballerini L, Angelotti ML, Parente E, Sagrinati C, Mazzinghi B, Peired A, Ronconi E, Becherucci F, Bani D, Gacci M, Carini M, Lazzeri E, Romagnani P: Notch activation differentially regulates renal progenitors proliferation and differentiation toward the podocyte lineage in glomerular disorders. Stem Cells 2010, 28:1674-1685.

61. Ronconi E, Sagrinati C, Angelotti ML, Lazzeri E, Mazzinghi B, Ballerini L, Parente E, Becherucci F, Gacci M, Carini M, Maggi E, Serio M, Vannelli GB, Lasagni L, Romagnani S, Romagnani P: Regeneration of glomerular podocytes by human renal progenitors. J Am Soc Nephrol 2009, 20:322-332.

62. Sagrinati C, Ronconi E, Lazzeri E, Lasagni L, Romagnani P: Stem-cell approaches for kidney repair: choosing the right cells. Trends Mol Med 2008, 14:277-285.

63. Sagrinati C, Netti GS, Mazzinghi B, Lazzeri E, Liotta F, Frosali F, Ronconi E, Meini C, Gacci M, Squecco R, Carini M, Gesualdo L, Francini F, Maggi E, Annunziato F, 
Lasagni L, Serio M, Romagnani S, Romagnani P: Isolation and characterization of multipotent progenitor cells from the Bowman's capsule of adult human kidneys. J Am Soc Nephrol 2006, 17:2443-2456.

64. Ye $Y$, Wang B, Jiang $X$, Hu W, Feng J, Li H, Jin M, Ying Y, Wang W, Mao X, Jin K: Proliferative capacity of stem/progenitor-like cells in the kidney may associate with the outcome of patients with acute tubular necrosis. Hum Pathol 2011, 42:1132-1141.

65. Swetha G, Chandra V, Phadnis S, Bhonde R: Glomerular parietal epithelial cells of adult murine kidney undergo EMT to generate cells with traits of renal progenitors. J Cell Mol Med 2011, 15:396-413.

66. Meyer-Schwesinger $C$, Lange $C$, Brocker $V$, Agustian PA, Lehmann U, Raabe A, Brinkmeyer M, Kobayashi E, Schiffer M, Busche G, Kreipe HH, Thaiss F, Becker JU: Bone marrow-derived progenitor cells do not contribute to podocyte turnover in the puromycin aminoglycoside and renal ablation models in rats. Am J Pathol 2011, 178:494-499.

67. Lazzeri E, Mazzinghi B, Romagnani P: Regeneration and the kidney. Curr Opin Nephrol Hypertens 2010, 19:248-253.

68. Appel D, Kershaw DB, Smeets B, Yuan G, Fuss A, Frye B, Elger M, Kriz W, Floege J, Moeller MJ: Recruitment of podocytes from glomerular parietal epithelial cells. J Am Soc Nephrol 2009, 20:333-343.

69. Albersen M, Fandel TM, Lin G, Wang G, Banie L, Lin CS, Lue TF: Injections of adipose tissue-derived stem cells and stem cell lysate improve recovery of erectile function in a rat model of cavernous nerve injury. J Sex Med 2010, 7:3331-3340

70. Pareta R, McQuilling JP, Farney AC, Opara EC: Bioartificial pancreas: evaluation of crucial barriers to clinical application. In Organ Donation and Transplantation - Public Policy and Clinical Perspectives. Edited by Randhawa G. InTech; 2012. http://www.intechopen.com/books/organdonation-and-transplantation-public-policy-and-clinical-perspectives/ bioartificial-pancreas-evaluation-of-crucial-barriers-to-clinical-application]

71. Moya ML, Lucas S, Francis-Sedlak M, Liu X, Garfinkel MR, Huang JJ, Cheng $\mathrm{MH}$, Opara EC, Brey EM: Sustained delivery of FGF-1 increases vascular density in comparison to bolus administration. Microvasc Res 2009, 78:142-147.

72. Moya ML, Garfinkel MR, Liu X, Lucas S, Opara EC, Greisler HP, Brey EM: Fibroblast growth factor-1 (FGF-1) loaded microbeads enhance local capillary neovascularization. J Surg Res 2010, 160:208-212.

73. Moya ML, Cheng MH, Huang JJ, Francis-Sedlak ME, Kao SW, Opara EC, Brey EM: The effect of FGF-1 loaded alginate microbeads on neovascularization and adipogenesis in a vascular pedicle model of adipose tissue engineering. Biomaterials 2010, 31:2816-2826.

74. Kang SW, Seo SW, Choi CY, Kim BS: Porous poly(lactic-co-glycolic acid) microsphere as cell culture substrate and cell transplantation vehicle for adipose tissue engineering. Tissue Eng Part C Methods 2008, 14:25-34

75. Yoo J, Meng J, Oberpenning F, Atala A: Bladder augmentation using allogenic bladder submucosa seeded with cells. Urology 1998, 51:221-225

76. Drewa $\mathrm{T}$ : The artificial conduit for urinary diversion in rats: a preliminary study. Transplant Proc 2007, 39:1647-1651.

77. Becker C, Olde Damink L, Laeufer T, Brehmer B, Heschel I, Jakse G: 'UroMaix' scaffolds: novel collagen matrices for application in tissue engineering of the urinary tract. Int J Artif Organs 2006, 29:764-771.

78. Oberpenning F, Meng J, Yoo JJ, Atala A: De novo reconstitution of a functional mammalian urinary bladder by tissue engineering. Nat Biotechnol 1999, 17:149-155.

79. Kobashi LI, Raible DA: Biocarbon urinary conduit: laboratory experience and clinical applications. Urology 1980, 16:27-32.

80. Woo KM, Chen VJ, Jung HM, Kim TI, Shin HI, Baek JH, Ryoo HM, Ma PX: Comparative evaluation of nanofibrous scaffolding for bone regeneration in critical-size calvarial defects. Tissue Eng Part A 2009, 15:2155-2162

81. Woo KM, Jun JH, Chen VJ, Seo J, Baek JH, Ryoo HM, Kim GS, Somerman MJ, Ma PX: Nano-fibrous scaffolding promotes osteoblast differentiation and biomineralization. Biomaterials 2007, 28:335-343.

82. Hu K, Cui F, Lv Q, Ma J, Feng Q, Xu L, Fan D: Preparation of fibroin/ recombinant human-like collagen scaffold to promote fibroblasts compatibility. J Biomed Mater Res A 2008, 84:483-490.

83. Gong Y, He L, Li J, Zhou Q, Ma Z, Gao C, Shen J: Hydrogel-filled polylactide porous scaffolds for cartilage tissue engineering. J Biomed Mater Res B Appl Biomater 2007, 82:192-204.

84. Wei G, Jin Q, Giannobile W, Ma PX: Nano-fibrous scaffold for controlled delivery of recombinant human PDGF-BB. J Control Release 2006, 112:103-110.
85. Liu X, Ma PX: Polymeric scaffolds for bone tissue engineering. Ann Biomed Eng 2004, 32:477-486.

86. Xie C, Hu J, Ma H, Zhang J, Chang L, Chen YE, Ma PX: Three-dimensional growth of iPS cell-derived smooth muscle cells on nanofibrous scaffolds. Biomaterials 2011, 32:4369-4375.

87. Torok E, Lutgehetmann M, Bierwolf J, Melbeck S, Dullmann J, Nashan B, Ma PX, Pollok JM: Primary human hepatocytes on biodegradable poly(l-lactic acid) matrices: a promising model for improving transplantation efficiency with tissue engineering. Liver Transp/ 2011, 17:104-114.

88. Hu J, Sun X, Ma H, Xie C, Chen YE, Ma PX: Porous nanofibrous PLLA scaffolds for vascular tissue engineering. Biomaterials 2010, 31:7971-7977.

89. Ma J, He X, Jabbari E: Osteogenic differentiation of marrow stromal cells on random and aligned electrospun poly(L-lactide) nanofibers. Ann Biomed Eng 2011, 39:14-25.

90. Feng K, Sun H, Bradley MA, Dupler EJ, Giannobile W, Ma PX: Novel antibacterial nanofibrous PLLA scaffolds. J Control Release 2010, 146:363-369.

91. Smith LA, Liu X, Hu J, Ma PX: The enhancement of human embryonic stem cell osteogenic differentiation with nano-fibrous scaffolding. Biomaterials 2010, 31:5526-5535.

92. He L, Liao S, Quan D, Ma K, Chan C, Ramakrishna S, Lu J: Synergistic effects of electrospun PLLA fiber dimension and pattern on neonatal mouse cerebellum C17.2 stem cells. Acta Biomater 2010, 6:2960-2969.

93. Liu X, Ma PX: The nanofibrous architecture of poly(L-lactic acid)-based functional copolymers. Biomaterials 2010, 31:259-269.

94. Wei G, Ma PX: Partially nanofibrous architecture of 3D tissue engineering scaffolds. Biomaterials 2009, 30:6426-6434.

95. Wang P, Hu J, Ma PX: The engineering of patient-specific, anatomically shaped, digits. Biomaterials 2009, 30:2735-2740.

96. Zhao H, Ma L, Gong Y, Gao C, Shen J: A polylactide/fibrin gel composite scaffold for cartilage tissue engineering: fabrication and an in vitro evaluation. J Mater Sci Mater Med 2009, 20:135-143.

97. Mei F, Zhong J, Yang X, Ouyang X, Zhang S, Hu X, Ma Q, Lu J, Ryu S, Deng $X$ : Improved biological characteristics of poly(L-lactic acid) electrospun membrane by incorporation of multiwalled carbon nanotubes/ hydroxyapatite nanoparticles. Biomacromolecules 2007, 8:3729-3735.

98. Gong Y, Zhu Y, Liu Y, Ma Z, Gao C, Shen J: Layer-by-layer assembly of chondroitin sulfate and collagen on aminolyzed poly(L-lactic acid) porous scaffolds to enhance their chondrogenesis. Acta Biomater 2007 3:677-685

99. Gelain F, Lomander A, Vescovi AL, Zhang S: Systematic studies of a selfassembling peptide nanofiber scaffold with other scaffolds. J Nanosci Nanotechnol 2007, 7:424-434

100. Woo KM, Seo J, Zhang R, Ma PX: Suppression of apoptosis by enhanced protein adsorption on polymer/hydroxyapatite composite scaffolds. Biomaterials 2007, 28:2622-2630.

101. Wei G, Jin Q, Giannobile WV, Ma PX: The enhancement of osteogenesis by nano-fibrous scaffolds incorporating rhBMP-7 nanospheres. Biomaterials 2007, 28:2087-2096

102. Torok E, Vogel C, Lutgehetmann M, Ma PX, Dandri M, Petersen J, Burda MR, Siebert K, Dullmann J, Rogiers X, Pollok JM: Morphological and functional analysis of rat hepatocyte spheroids generated on poly(L-lactic acid) polymer in a pulsatile flow bioreactor. Tissue Eng 2006, 12:1881-1890.

103. Wei G, Ma PX: Macroporous and nanofibrous polymer scaffolds and polymer/bone-like apatite composite scaffolds generated by sugar spheres. J Biomed Mater Res A 2006, 78:306-315.

104. Liu X, Won Y, Ma PX: Porogen-induced surface modification of nanofibrous poly(L-lactic acid) scaffolds for tissue engineering. Biomaterials 2006, 27:3980-3987.

105. Chen VJ, Smith LA, Ma PX: Bone regeneration on computer-designed nano-fibrous scaffolds. Biomaterials 2006, 27:3973-3979.

106. Chen VJ, Ma PX: The effect of surface area on the degradation rate of nano-fibrous poly(L-lactic acid) foams. Biomaterials 2006, 27:3708-3715

107. Ma Z, Gao C, Gong Y, Shen J: Cartilage tissue engineering PLLA scaffold with surface immobilized collagen and basic fibroblast growth factor. Biomaterials 2005, 26:1253-1259.

108. Wu X, Rabkin-Aikawa E, Guleserian KJ, Perry TE, Masuda Y, Sutherland FW, Schoen FJ, Mayer JE Jr, Bischoff J: Tissue-engineered microvessels on three-dimensional biodegradable scaffolds using human endothelial progenitor cells. Am J Physiol Heart Circ Physiol 2004, 287: $\mathrm{H} 480-\mathrm{H} 487$ 
109. Wei G, Ma PX: Structure and properties of nano-hydroxyapatite/polymer composite scaffolds for bone tissue engineering. Biomaterials 2004, 25:4749-4757.

110. Chen VJ, Ma PX: Nano-fibrous poly(L-lactic acid) scaffolds with interconnected spherical macropores. Biomaterials 2004, 25:2065-2073.

111. Yang F, Murugan R, Ramakrishna S, Wang X, Ma YX, Wang S: Fabrication of nano-structured porous PLLA scaffold intended for nerve tissue engineering. Biomaterials 2004, 25:1891-1900.

112. Aamer KA, Sardinha H, Bhatia SR, Tew GN: Rheological studies of PLLAPEO-PLLA triblock copolymer hydrogels. Biomaterials 2004, 25:1087-1093.

113. Ma Z, Gao C, Gong Y, Shen J: Paraffin spheres as porogen to fabricate poly(L-lactic acid) scaffolds with improved cytocompatibility for cartilage tissue engineering. J Biomed Mater Res B Appl Biomater 2003, 67:610-617.

114. Fuchs JR, Pomerantseva I, Ochoa ER, Vacanti JP, Fauza DO: Fetal tissue engineering: in vitro analysis of muscle constructs. J Pediatr Surg 2003, 38:1348-1353.

115. Ma Z, Gao C, Shen J: Surface modification of poly-L-lactic acid (PLLA) membrane by grafting acrylamide: an effective way to improve cytocompatibility for chondrocytes. J Biomater Sci Polym Ed 2003, 14:13-25.

116. Torok E, Pollok JM, Ma PX, Vogel C, Dandri M, Petersen J, Burda MR, Kaufmann PM, Kluth D, Rogiers X: Hepatic tissue engineering on 3dimensional biodegradable polymers within a pulsatile flow bioreactor. Dig Surg 2001, 18:196-203.

117. Torok E, Pollok JM, Ma PX, Kaufmann PM, Dandri M, Petersen J, Burda MR, Kluth D, Perner F, Rogiers X: Optimization of hepatocyte spheroid formation for hepatic tissue engineering on three-dimensional biodegradable polymer within a flow bioreactor prior to implantation. Cells Tissues Organs 2001, 169:34-41.

118. Ma PX, Choi JW: Biodegradable polymer scaffolds with well-defined interconnected spherical pore network. Tissue Eng 2001, 7:23-33.

119. Ma PX, Zhang R, Xiao G, Franceschi R: Engineering new bone tissue in vitro on highly porous poly(alpha-hydroxyl acids)/hydroxyapatite composite scaffolds. J Biomed Mater Res 2001, 54:284-293.

120. Song M, Heo J, Chun JY, Bae HS, Kang JW, Kang H, Cho YM, Kim SW, Shin DM, Choo MS: The paracrine effects of mesenchymal stem cells stimulate the regeneration capacity of endogenous stem cells in the repair of a bladder-outlet-obstruction-induced overactive bladder. Stem Cells Dev 2013, 23:654-663.

121. Davies NH, Schmidt C, Bezuidenhout D, Zilla P: Sustaining neovascularization of a scaffold through staged release of vascular endothelial growth factor-A and platelet-derived growth factor-BB. Tissue Eng Part A 2012, 18:26-34.

122. Zhou L, Yang B, Sun C, Qiu X, Sun Z, Chen Y, Zhang Y, Dai Y: Coadministration of platelet-derived growth factor-BB and vascular endothelial growth factor with bladder acellular matrix enhances smooth muscle regeneration and vascularization for bladder augmentation in a rabbit model. Tissue Eng Part A 2013, 19:264-276.

\section{$10.1186 /$ scrt458}

Cite this article as: Qin et al:: Urine-derived stem cells for potential use in bladder repair. Stem Cell Research \& Therapy 2014, 5:69 